\title{
Enclaves of Improvement: Sovereignty and Developmentalism in the Special Zones of the China-Lao Borderlands
}

\author{
PÁL NYÍRI \\ Vrije Universiteit, Amsterdam
}

Join the struggle against drugs, build a harmonious society!

Chinese-language banner, Golden Boten City Special Economic

Zone, Laos

We academics have found it difficult to "think ourselves beyond the nation" (Appadurai 1993: 411). After an early post-Cold War enthusiasm for discovering post-national forms of identity, which were expected to emerge from the experiences of migrants or diasporas (e.g., Boyarin and Boyarin 1993; Gilroy 1993; Appadurai 1996; Clifford 1997), we found that neither the nation, nor the state, nor their combination were losing power or appeal. Despite a proliferation of writing that explored new forms of sovereignty, in the end few of them materialized. While it has been easy to identify nationalist movements decoupled from territorial states, and many states have reclaimed some form of cultural sovereignty over their diasporas, there is little evidence of groups attempting to organize themselves into entirely post-national polities. The theoretical hopes articulated twenty years ago for a post-national world order have remained decoupled from realities on the ground, and have gradually faded.

And yet, some anomalous and ambiguous forms of territoriality and sovereignty that have actually emerged have largely escaped our notice, until recently. Particularly since the publication of the English translation of Giorgio Agamben's State of Exception (2005), spaces in which normal rules of the state are suspended have attracted growing attention, notably from Aihwa Ong (2006), who has a longstanding interest in what she calls forms of "graduated sovereignty" in Southeast Asia (2000). James Ferguson has

Acknowledgements: My thanks to Xiang Biao and the anonymous CSSH reviewers for their insightful comments on an earlier version of this paper and to Miriam Weihe for sharing documents and ideas. The paper benefited from a discussion at the panel "Asian Border-Crossing Mobilities: On the Road to (Self)Development," at the 2011 Annual Meeting of the Association for Asian Studies. 
pointed to the "enclaved mineral-rich patches" in Africa, where "security [is] provided ... by specialized corporations while the ... nominal holders of sovereignty ... certify the industry's legality ... in exchange for a piece of the action." He likened this approach to pre-colonial European mercantilist logic, and contrasted it with the developmental logic of the mature colonial and postcolonial state (2006: 204). Most scholars have conceived of these spaces of exception, or of graduated sovereignty-free trade zones, export processing zones, and the like - as areas carved out of national territories, following the profit-maximizing logic of neoliberal flexibility, but ultimately under the control of the nation-state elites, nonetheless.

On the other hand, significant scholarship, most notably in anthropology, has explored the anomalies of sovereignty in borderlands. This line of thought goes back to Edmund Leach $(1954 ; 1960)$, who noted that the highland polities of Burma had long maintained a zone of ambiguous or multiple allegiances, never truly incorporated into any of the lowland kingdoms that claimed overlordship above them. Many writers have built upon Leach's approach, most recently and famously van Schendel (e.g., 2002) and Scott (e.g., 2009), who argue that some societies of the uplands (and almost always the borderlands) of Southeast Asia have resisted the nation-state-making projects of lowland polities. ${ }^{1}$ But in the literature that analyzes highland/borderland polities from the perspective of state evasion, these societies appear as valiant atavisms resisting the logic of nation-state modernity (see Walker 1999).

That scholarship celebrating such "non-state places" risks implying that they remain outside of modernity is not its only pitfall. Due to the Cold War heritage of Southeast Asian studies, pockets of resistance against the lowland states have received more attention and sympathy than has resistance against postcolonial nation-states in Africa. Western academics have always given much more explicit support to postcolonial state-building in Africa, and only recently have scholars like Frederick Cooper taken a more critical look at the creation of individual African nation-states and started to take more seriously the alternatives that may have been available, including plans for a Frenchspeaking commonwealth (see Cooper 2011). Despite all the criticisms of both the idea and the practice of national sovereignty, the twentieth-century maxim that it is a necessary condition of modernization has yet to be seriously questioned.

Conversely, certain forms of ambiguous sovereignty imposed by the intrusive logic of modernization, such as enclaves run by Western mining companies in poor countries, have largely escaped ethnographic scrutiny despite

\footnotetext{
1 Much of the historical scholarship on the "fuzziness" of premodern sovereignty is based on Southeast Asia and China, for example Tambiah (1977), Keyes (1979), Thongchai (1994), Hevia (1995), and Smith (1998). Leach's original argument has recently been revisited in a volume edited by Sadan and Robinne (2007).
} 
frequent reference to them as testimony to persistent imperialism. On the whole, such polities have been seen as marginal or epiphenomenal to the grand scheme of neoliberal globalization - as its freakish outcomes or its leftbehind discontents - or else as internal to the scheme's manipulation by nationstate elites (e.g., Ferguson 2006). These situations are a far cry from the liberation that early-1990s theorists hoped post-national sovereignty would bring about, and from forms of sovereignty akin to the protectorate or the United Nations mandate territory, which some political scientists have suggested reintroducing based on the experiences of "failed states" and the military occupations of Afghanistan and Iraq (e.g., Krasner 2004).

Against this background, the present article calls attention to a situation in the China-Laos borderlands in which something like post-national sovereignty is actually practiced; not in the sense that the two nation-states do not matter, but rather in that, while both possess aspects of sovereign control over the territories and people in question, much of the sovereignty is vested in a private corporation. This corporation, in turn, borrows the administrative and symbolic trappings of one and sometimes both states to bolster its own legitimacy. Despite their geographic marginality, the "special zones" of the Lao borderlands position themselves as the new engines of dynamism that will bring the backward lowland states into the whirlwind of modernity, and in fact they have achieved some success. They cast themselves as doubly modern by simultaneously deploying the regalia of the Chinese state, which stand in the region for the strong, successful, modernizing state, and a pioneer discourse of economic and social freedom from the strictures of that very state, also in the name of modernity. What this discursive strategy both expresses and grants legitimacy to is the meshing of state and non-state fantasies of development.

Although the region described here is peripheral to major economic and population centers, the developments unfolding there are part of a massive global expansion of capital and population from China, reaching from Eastern Europe into the Pacific. Much Western commentary treats it as statedirected imperialism or neocolonialism. I will argue here that investigation of the role of private concessionaries in generating anomalous forms of sovereignty - to which, today as before, there is much more than simply the inexorable expansion of (neo)liberal logic - reveals a more productive parallel with Western imperialist dominions. The current debate over whether or not China is becoming a neocolonial power is largely determined by political sympathies and ideological dichotomies, and serves little analytical purpose. Yet the manner, scale, and discursive justification with which various Chinese state and private parties engage with low-income countries warrants a fresh look at the relationship between national sovereignty and modernization, and this relationship begs comparison with both colonial and immediate postcolonial configurations. 
THE RISE AND FALL OF THE GOLDEN BOTEN CITY SPECIAL ECONOMIC ZONE 2

Golden Boten City (GBC) was opened in 2007 as a land concession across the Chinese border in northern Laos. Fokhing, a Hong Kong-registered company, has leased the 16 square kilometer area for thirty years, with the option of renewing the lease twice. Its central feature is a hotel-casino complex. In the beginning, virtually everything and everyone in the place were Chinese, from the employees and small business owners (estimated by GBC's managers at 3,000 in 2008 and 4,800 in the peak season of 2010) ) $^{3}$ to the currency (only yuan were accepted), and the beer. Until December 2010, both the fixed and mobile phone networks and the Internet also came from China, and the zone even runs on Peking time, one hour ahead of Laos. Members of a seven hundred-strong security force manned a booth at each entry to the zone and marched around in military formations in uniforms resembling those of Chinese police, emblazoned with "Special Zone Security" in Chinese characters. Lao casino staff say that, in the past, Chinese citizens accused of the crimes and also bodies of Chinese murder victims were whisked quietly back over the border.

According to a report written at the end of 2010, the zone by then had three hundred Lao employees, but they were visible only in low-skilled jobs such as maids or bellboys. The zone's general manager claimed that some one thousand Lao worked there, including those running small businesses along its edges. There are also some Burmese employees. Wages are higher in the zone than in either Laos or China's surrounding provinces: in 2011, cleaning jobs were being advertised that paid 1,800 yuan (US\$300) a month plus room and board. ${ }^{4}$

From the outset, the company's management has styled GBC as a tequ, or special zone, but the Lao government did not officially gazette it until the turn of the last decade. ${ }^{5}$ Under the statutes, the zone is governed by an Economic Committee and an Administrative Committee. Members of the former are appointed by the investors, most notably by GBC Chairman Huang Mingxuan, a Hong Kong resident originally from southern Fujian Province who formerly operated a gambling hall in Mong La just across the China-Burma border. As head of the Economic Committee he has delegated management positions to several relatives from his home village. The Committee's office is a four-story

\footnotetext{
${ }^{2}$ Except where indicated, this and the following section are based on three periods of ethnographic fieldwork between 2008 and 2011, one of which included a visit to northern Burma. The first of these was carried out jointly with Chris Lyttleton (see Lyttleton and Nyíri 2011).

3 These included shopkeepers from Yunnan across the border, prostitutes from Sichuan and Heilongjiang in the northeast, and snack stall keepers from Fujian, Hunan, and Zhejiang in the southeast of the country.

4 All dollar amounts given are in U.S. dollars.

5 Zone administrations refer to late 2009 or early 2010 as the date GBC and the Golden Triangle Special Economic Zones were established (Vientiane Times 2009; Hanzi 2010).
} 
building across the road from GBC. In the meeting room hang photos of GBC leaders with Lao government officials, including the powerful former president, Khamtay Siphandone. The nineteen members of the Administrative Committee are appointed by the Lao prime minister's office but, for now, the investing company pays them. A yearly, increasing concession fee has been fixed in advance: $\$ 700,000$ until 2010 , $\$ 2$ million in 2011-2013, and $\$ 2.4$ million in 2014-2015 (Pinkaew 2011). In return for this fee, the Economic Committee has the right to levy its own taxes and administrative fees, and the intention is to use these to pay the members of the Administrative Committee. The taxes are retained by the zone's administration, except for a small amount which, the general manager told me, is used for "aid given to neighboring towns." The administration can also enact legislation, and issues license plates and ID cards that are different from those in the rest of Laos but valid across the country. ${ }^{6}$

GBC's general manager stressed that the territory is Lao, but Chinese-English bilingual street names, the second-hand Chinese police van, the uniforms, the currency, banners with slogans about harmonious society, and the television channels all reproduce what Benedict Anderson called the "regalia" (1993: 183) of the Chinese state, even though the zone's managers may well see them as, above all, paraphernalia of modernity. When I asked the zone's office manager, an ethnic Tai woman from Sipsongpanna across the border in China, why they fly banners with slogans promoted by the Chinese government, she replied, "Those things that Laos does not have, we need to borrow." The check-in procedure at the hotel follows Chinese rules, which means that everyone, including Lao citizens, must show their passports, which are dutifully copied by the Chinese reception staff.

In 2010, a unit of Lao police was added to the Chinese security force to form a new public safety department under the zone's Administrative Committee. More significantly, the Lao border post, which was initially sited beyond the special zone border so that Chinese visitors did not have to deal with Lao immigration, has been moved and casino visitors must now pass through it. The new post, like the old one, is little more than a single-story shed, and contrasts sharply with the spanking new Chinese border station.

Despite the clear subordination and near-invisibility of Lao workers, there are indications that relations between Chinese and Lao are negotiated in complex ways. During my visit to GBC in August 2010, I overheard a phone call the general manager's assistant made regarding a Lao casino dealer who had been hit and killed by a car while riding her motorcycle. Although the driver was unknown, the company had paid the family 40,000 yuan, or about $\$ 8,000$.

\footnotetext{
6 These rights are affirmed in Articles 62, 63, and 94 of the vaguely phrased prime minister's Decree 443/PM, which was, however, issued after the zone began issuing license plates.
} 
According to the managing director of the zone, the Administrative Committee said that $\$ 130$ million had been invested in the zone as of mid-2010. Three large hotels and a nightclub called "Quanqiucun" (global village) have been built, along with some fifty four- and five-story buildings that house workers' dormitories, shops, and apartments for sale. According to a report written for a November 2010 visit of the chairman of the Lao National Assembly, the zone administration had also constructed two new customs buildings and a primary school, and had prepared 10 hectares of ground for the houses of relocated villagers and a relocated salt factory. Whereas in 2008 the zone was dark at night, by 2010 it was illuminated by the shimmering neon signs of the night entertainment venues. Accommodation capacity has grown to twenty-seven hundred rooms, and the general manager told me investment had come from Thailand, Singapore, Russia, Ukraine, and the United Kingdom, although by early 2011 some of these investors were withdrawing and as many as a thousand small merchants had left.

In early 2010, a series of reports in Chinese media alleged that security staff at Boten falsely detained and tortured Chinese gamblers who were unable to pay their debts, in order to force their families to pay. The Foreign Ministry issued a statement warning Chinese nationals against going to Laos to gamble due to the risk of scams and kidnappings (MqVU 2010). In the spring of that year, Chinese border guards began turning back Chinese citizens who had not obtained visas in advance, even though Lao regulations allow them to obtain them at the Lao border. Border passes, valid only for a limited area of Laos, became harder to get. These measures were clearly intended to disrupt the business of recruiters who had been arranging gamblers' travel packages. Then, in December 2010, Yunnan Province's police department ordered the three Chinese telephone companies operating in Boten to cut their services. GBC switched to more expensive Lao providers, but by the following January the combination of these two sanctions had reduced the inflow of gamblers to a trickle, and five of the twelve companies operating gambling halls had pulled out. Meanwhile, the prefectural police department of Sipsongpanna demanded that GBC hand over some fifty gambling hall operators and employees wanted on charges of inducement to gamble and facilitating illegal border crossing. In April 2011, the last and largest gambling hall closed after its owner, a Philippine citizen, was arrested in Shanghai on unrelated charges, and by May the largest hotel was closed. The zone's population now numbered one-tenth of what it had been in its heyday.

Under pressure from China, the zone's management now appealed to the Lao government for support to, in the words of the office manager, "liaise with China on opening up border tourism and resolving the issues of visa on arrival and border passes." The manager explained to me that they planned to "enthusiastically support the Lao government" in financing the Lao section of a new Yunnan-Singapore railway, for which the government is seeking investors. The 
rights of special zones had been formalized in a vaguely phrased government decree in October 2010, at a time of increasing Chinese pressure and growing unease in Laos following negative online coverage (state media did not report on the alleged kidnappings and torture). This decree could be read either as an effort to place limits on the sovereignty of the zones or, conversely, as a move to cement their legitimacy. Its text suggests the latter: it makes no provisions for protecting the rights of residents or employees or for settling disputes, while it charges the Economic Committee rather than the Administrative Committee with ensuring "cultural, social, education and public health development" as well as with "security and order," and with allocating land (Decree no. 443/PM, Article 94). It also asks the district within which the zone is located and surrounding village administrations to provide vocational training for residents, protect Special Economic Zone facilities, and foster the growth of local business (Articles 87-88).

Despite the demise of the company, the special zone lives on, and a company based in Yunnan Province acquired GBC from its original owners. Golden Boten, deserted though it is, remains a monument to the Chinese version of urban modernity matched by no other place in Laos. At the same time, the moving of the immigration post, the dispute over the security force and the conflict over the handling of suspects in the criminal case that led to the company's downfall, and the new decree all suggest that its sovereignty remains contested. The Hong Kong registration of the original investment company and the Taiwanese nationality of the former general manager also confound any conclusion that this zone is simply an extension of the People's Republic of China; instead, they deliberately, intentionally suggest a promise of deterritorialized Chinese modernity (Ong 1999).

MACHINE GUNS, GOLDEN CHOPSTICKS, AND ORGANIC AGRICULTURE IN THE GOLDEN TRIANGLE SPECIAL ECONOMIC ZONE

The Golden Triangle Special Economic Zone in Bokeo Province, across the Mekong from Thailand, was gazetted in February 2010. The Lao government had granted the Hong Kong-registered KingsRomans Group a concession to the area in $2007 .^{7}$ In 2010, a zone manager told me that the first year's concession fee was around $\$ 850,000$, but a driver said that one-time personal payments of $\$ 5$ million were made to both the prime minister and the president.

News reports, citing the Lao government as a source, identified the area of the concession as 827 hectares and reported the duration of the concession was seventy-five years (Voice of America Lao Service 2010), but recent company documents say the concession is for 103 square kilometers - ten times larger —and ninety-nine years (Hanzi 2010: 13; KingsRomans 2010). Like his

7 At: www.kingsromans.com (accessed 25 July 2010). 


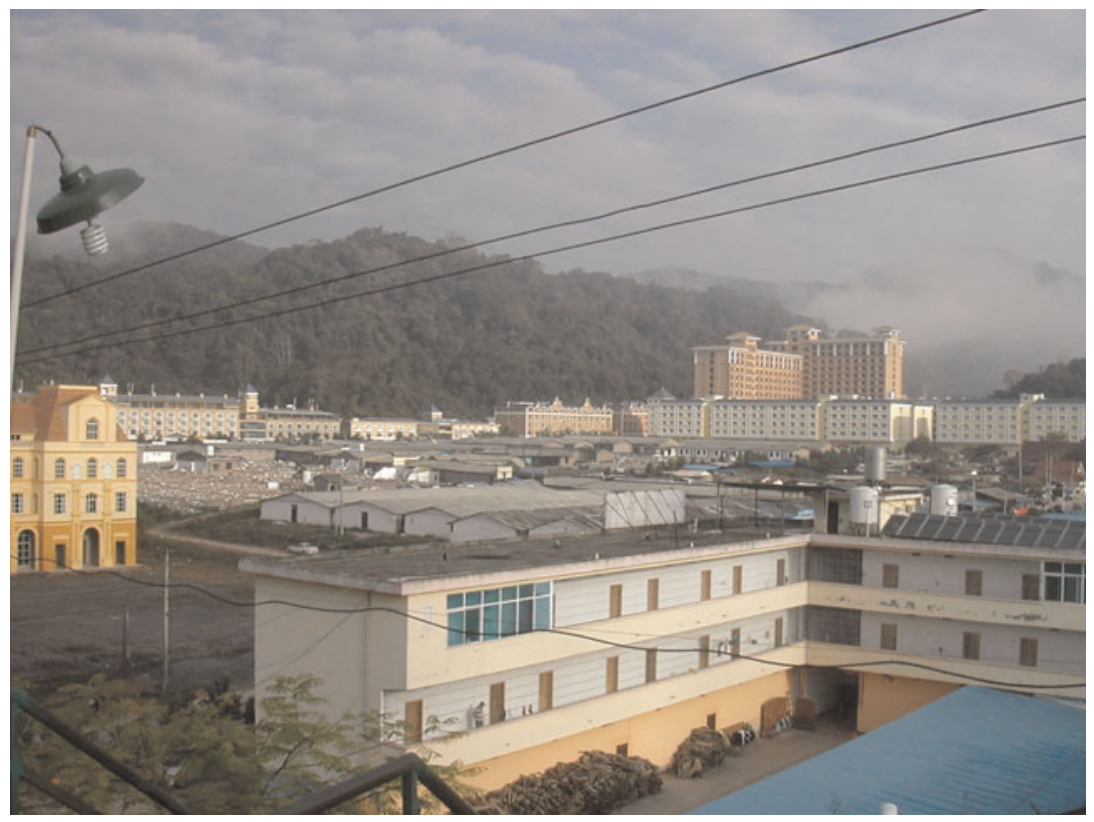

FIgURE 1 Golden Boten City, January 2011. Author's photo.

counterpart in Boten, the chairman of KingsRomans and of the zone's management committee, Zhao Wei, once operated a gambling hall in Mong La, a threehour speedboat ride up the Mekong. Zhao was born in northeast China and is a Macau resident; his Macau company, the Yinhe Group, is an investor in the two casinos that have operated in the zone since 2009. These casinos are larger in scale than in those in Boten, and the newest one was designed by a Portuguese architect who has also designed Macau casinos. In late 2010, Zhao said KingsRomans had invested more than $\$ 500$ million and had fifteen hundred employees (Hanzi 2010: 13-15), although as of mid-2009 only \$26 million of that had been registered by the Planning and Investment Department of Bokeo Province (Tan 2010: 23, n. 41). In 2010, employees estimated the zone's population at about two thousand, but a year later estimates varied between six and ten thousand, excluding some five thousand Lao peasants who inhabit seven villages in the zone. According to a KingsRomans public relations officer-a man from northern China in his late twenties who had moved to the zone from Dubai where, he told me, he had worked as an interpreter-about one thousand of these people work for the company or sell produce to it.

The zone is near the Thai end of Route 3, the new road that links Thailand to China and whose other end is at Boten. But unlike Boten, this zone is not along the road but on farmland 50 kilometers north of it. Much of the 
investment has been in basic infrastructure: reinforcing the riverbank and building roads, a water-bottling plant, and the houses for 114 farming households to be resettled within the zone. The company has planted over 1,000 mu (about 67 hectares) of maize, wet rice, vegetables, various types of commercial forest, a fruit orchard, and flowers, and raises some four hundred pigs, five hundred head of cattle, and poultry. Plans for the future include developing "organic sightseeing farming" with the help of specialists from China (Hanzi 2010: 15). Some produce is already being sold outside the zone, and this is said to be undercutting Lao market prices. ${ }^{8}$

A well-known Chinese planning firm executed the master plan for the zone, of which a scale model is on display in a special building. The same firm was responsible for Overseas Chinese City in Shenzhen, a hallmark of special zone urban modernity in early 1990s China. The plan includes several hotels, an island resort, a golf course, a hospital, and a school. Completed so far are two casinos, five hotels, a nightclub, a shopping arcade, a covered market, a larger shopping center, a farmer's market, and a large number of dormitories and single-story houses for families. Two-thirds of the area consists of hills that will be left undeveloped as a nature reserve; the swidden agriculture traditionally practiced by the area's mountain dwellers will be forbidden there. While many Chinese invest in rubber plantations in northern Laos, Zhao Wei has prohibited rubber planting in the zone since he plans to develop it as a base for regional tourism.

These tourism plans appear to rely on the Golden Triangle's aura of crime, mystery, and opulence. The promotional brochure features photos of guests reclining on leopard skins and eating from golden bowls with golden chopsticks, firing M-16 assault rifles and Uzi submachine guns at the shooting range, and riding elephants and petting giant snakes. They also show a Thai kickboxing contest and a racetrack. The Kapok Festival in February, which marks the flowering of the trees, is a cross between an official holiday and a signature tourist event. In 2011, it included a meeting of regional tour operators, a music and dance show with performers from China, Burma, Thailand, and Laos, an international crafts fair, and a beauty contest. In addition to tourism, long-term plans include developing a "logistics, finance, communications, and media" hub. All of these investments are described in terms of opium substitution. ${ }^{9}$

Thai and Chinese companies offer telephone network coverage. Electricity comes from Thailand, but the sockets are Chinese. Like Boten, the zone is on Peking time. The statutes governing the zone's legal status seem to be the same as those for Boten, but Golden Triangle's managers have made more of the zone's autonomy, which covers "everything except defense,

8 Deng Rui, personal communication, 2010.

9 At: http://www.laosez.com/html/tqgk/ (accessed 16 Feb. 2011). 


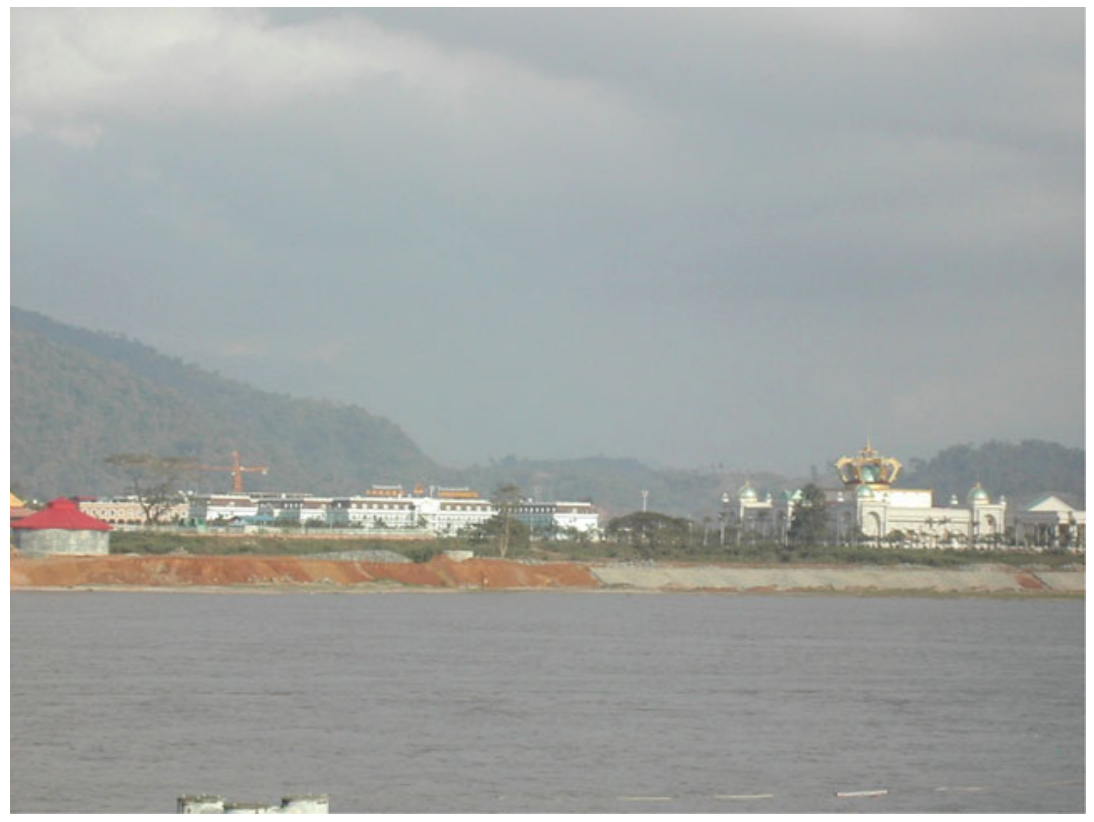

Figure 2 The Golden Triangle Special Economic Zone seen from Chiang Saen, January 2011. Author's photo.

foreign relations, and legislation" (Hanzi 2010: 13). Zhao Wei, known as "Chairman Zhao," makes public appearances akin to those made by Chinese officials, and zone managers are referred to as "cadres." Here, too, one sees anti-drug posters and banners, and two "notices" (tonggao) issued by the Administrative Committee and signed by Zhao Wei are pasted to the walls: one "Strictly Forbidding the Consumption and Trafficking in Drugs," and another "Strictly Forbidding the Illegal Possession of Firearms and Explosives." Like all official communication, they are written in the prose of Chinese government documents. They warn that violators will be fined 50,000 yuan by the Safety Office and dealt with according to Lao law.

The Safety Office comprises about one hundred Lao policemen and, under separate command, a detachment of Chinese and Burmese security guards. Lao police can be seen patrolling the rural parts of the zone in brand-new cars - presumably bought by the zone administration - but not around the casinos, suggesting an informal division of jurisdiction but also serving as a reminder that here, too, the limits of extraterritoriality are open to contestation.

According to one news report, one of Zhao's assistants is a former rural government official from China, while another previously served as a diplomat at the Chinese embassy in Vientiane (Fawthrop 2011). On the Lao side, the 
chairman of the Administrative Committee is a Lao police official with a degree from Vietnam, while the vice-chairman is a member of the Lao National Assembly. Street signs, like official documents, are trilingual (Lao, English, and Chinese), but West Garden Road, the main riverside avenue, is lined with weather-beaten Lao national and Party flags, perhaps left over from a high-ranking official's visit. A brochure promoting the zone features photos of Zhao Wei with Party General Secretary Choummaly Sayasone, Premier Thongsing Thammavong, and other dignitaries. ${ }^{10}$

Unlike the much smaller Boten, the Golden Triangle zone lacks a direct boundary with China, which makes direct Chinese intervention there impossible. Many guests arrive via Thailand. KingsRomans charters flights from Macau and Bangkok to Chiang Rai, about an hour's drive across the Thai border. A helicopter ferries VIPs from Chiang Rai airport, the Chinese border, and Vientiane, while less important guests make do with a fleet of Cadillac stretch limos - during one of my visits a group of Yunnan Province officials arrived in them to "inspect" the Kunming-Bangkok highway.

Like the clientele, the zone's workforce is more multinational than Boten's. While petty traders and prostitutes tend to be Chinese, construction workers are mostly Burmese, and even some Lao farms within the zone reportedly employ Burmese farmhands. Company, casino, and hotel staff are a mix of Chinese, Thai, and Burmese, and the zone's Lao farming population may become more visible with the construction of farmer's markets. Many of the early employees moved to the zone with the investors from Mong La and were later joined by friends and relatives. A wave of shop and stall keepers, prostitutes, and other petty entrepreneurs also arrived from Sichuan, Fujian, Hunan, and northeastern China, and a handful came from Burma and Thailand. Investors often recruit workers in their own hometowns, setting off new migration chains.

Although most migrants come from rural areas, the zone also attracts all sorts of fortune-seekers. For example, one Thai man from Chiang Saen on the Thai side of the Mekong arrived after earning a university degree in Bangkok and studying English in Oxford. He came to help his sister, a shareholder in a gambling hall, run her jewelry shop. A noodle vendor arrived from Ayuttaya, near Bangkok. A Shan man from Burma who helps his brother run a food stall and speaks excellent Mandarin arrived following stints of work in Malaysia and Thailand. In the zone he met his wife, an ethnic Hani woman from China employed by a shop that sells credit for Chinese mobile phones. Those other than common laborers all speak some Chinese, and the higher their position the more important this is. As a Lao woman explained to me,

\footnotetext{
${ }^{10}$ Apart from frequent official visits, the zone also plays host to families of officials on their way to or from Thailand: just before one of my visits, they had entertained Choummaly's two grandchildren.
} 
it is easy to find a job with good wages, but you can only keep it if you learn some Chinese. Ethnic Chinese from northern Thailand and Burma often work in positions of some trust, for example as drivers or bodyguards. Wages are similar to those in Boten, but here there is an ethnic hierarchy: Burmese construction workers' monthly wages start at from $\$ 120$ to $\$ 150$, and those of KingsRomans' Lao employees at $\$ 150$ to $\$ 200$, while Chinese workers receive a 400 yuan supplement for "working abroad."

\section{A GENEALOGY OF SPECIAL ZONES}

Over the last five years, China has been the leading source of investment in Laos, and Chinese companies are far and away the most important builders of roads, bridges, dams, and most recently railways, largely using concessional loans backed by the Chinese state (International Rivers 2008; Lyttleton and Nyíri 2011). China has earmarked $\$ 771$ million for twenty-one infrastructure projects to be carried out from 2011-2015 (Khaosan Pathet Lao 2010). In northern Laos, the most significant driver of recent economic and social change has been Chinese investments in contract farming (mostly rubber and cassava), mining, and retail trade, all facilitated by Chinese-built roads (Shi 2008). These investments have brought with them a large number of Chinese migrants, ranging from construction and mine workers to small traders, who now dominate the markets for consumer goods and, increasingly, sell agricultural produce.

In the borderlands, working for a Chinese business has become the most accessible option for upward mobility, and more and more non-Chinese children are attending a growing number of Chinese schools. In the Northern Lao town of Luang Namtha, for example, enrolment in the Chinese school rose from around 30 in 2008, to 475 in 2011. Members of some ethnic groups in the north of Burma, Laos, and Thailand are once again emphasizing their historical connections to China, this time because of its connotations of economic progress (Toyota 2002; Diana 2009; Le Bail and Tournier 2010). ${ }^{11}$

The mountainous borderlands of northern Laos are part of the region that James Scott (borrowing van Schendel's term) called "Zomia." Leach and many subsequent scholars have based their arguments about "fuzzy sovereignty" on this area's history. Throughout most of the twentieth century this particular corner of "Zomia" hosted numerous insurgencies, drug-fuelled and otherwise,

11 Many travelers and scholars (Walker 1892; Scott 1932; Leach 1960; Prescott 1977; Forbes and Henley 1997; Hill 1998; Davis 2003; Edwards 2005) have noted that the highland polities of Burma, and the neighboring areas of contemporary Thailand and Laos, have a long history not only of imperial Chinese influence that ranges from material culture to political organization, but also of small-scale Chinese immigration of traders and farmers from Yunnan Province. One high-ranking British colonial official even suggested that parts of the borderlands be made into a Sino-British condominium (Edwards 2005: 220). The final demarcation of the border did not take place until 1941 . 
and there remain pockets of armed resistance. The end of the Cold War, however, brought fundamental changes. As borders opened, regional cooperation increased, cash flowed in, and arms supplies dried up, insurgents began to engage with lowland states in new ways.

Huang Mingxuan and Zhao Wei both made some of their money in Burma's Shan State Special Zone 4, controlled by a remnant of the Burmese Communist Party insurgency that dates back to the 1950s. The special zones that Huang and Zhao now run, from the administrative structure down to the street signs, are clearly inspired by Special Zone 4. Yet Huang and Zhao's move from Burma to Laos reflects a broader shift in the interaction between states, private capital, and ideologies of governance in the region. Formerly Zomian enclaves and their ruling elites - in many cases former insurgents who have turned to business - have benefited from the high international profile of "special economic zones" as a ("Chinese") model of economic development (Brautigam and Tang Xiaoyang 2011), and from the growing popularity of concessionary land leases among governments of poor countries (Bayart et al. 2004; Cotula et al. 2009). They want to hedge against encroachment by lowland states, and are joining legitimate international circuits and linking up with global and regional economic opportunities, particularly the infrastructural initiative known as the Greater Mekong Subregion (Lyttleton et al. 2004; Edwards 2005; Glassman 2010). Seeking respectability, they have embraced the developmentalist discourse of "transport corridors" that the Asian Development Bank and China have promoted in the region, and they are benefiting more broadly from the growing clout of China in regards the region's development hopes.

Although Zhao and Wei were late arrivals in Special Zone 4 and never became part of its leadership, the genealogy of the enclaved government they now champion reaches back to the early 1950s, when the small ethnic Chinese population of northern Thailand, Burma, and Laos-known locally as Haw-expanded due to an influx of defeated soldiers, stragglers, "bandits," and refugees after the Communist victory in China. They and their descendants formed distinct villages, intermarried with non-Chinese, and generally fit into the pattern of "hill tribes." Yet they attained greater prosperity and soon became models for agricultural innovation for the surrounding areas on account of their "obviously superior way of life" (Mote 1967: 518). In the early years, Kuomintang generals acted as the de facto rulers of Yunnanese Chinese and their family members, about ninety thousand people in all (Chang 2001). They appointed village headmen, maintained armies, and served as patrons of the opium, arms, and gems trades across the Burma-Thailand border. Khun Sa, a Chinese-Shan warlord whose Shan United Army went on to control much of that border between 1985 and 1996, trained with Kuomintang troops in the 1950s and 1960s (McCoy 1999).

From 1968 until 1982, China provided military support, instructors, and volunteers for the Burmese People's Army (BPA) of the Communist Party of 
Burma (CPB), which was instrumental in routing the Kuomintang from Burma to Thailand. In its heyday, the BPA controlled an area of over 20,000 square kilometers along the Yunnan border and commanded more than twenty thousand mostly local "hill tribe" troops. Some of the BPA commanders were ethnic Chinese from lowland Burmese cities (Guo 2007: 42). At the turn of the 1970s, the BPA's ranks were joined by thousands of "educated youths" (zhiqing): urban youths who had been sent down to the Yunnan countryside after Mao Zedong decided to curb the spontaneous violence of the first three years of the Cultural Revolution (51nb.com 2009). Some of these youths, driven by the ideals of heroism they had been taught, but often deemed unworthy for their "bad" class backgrounds, sought to prove themselves in the Burmese revolution. Others wanted to escape the hardships of their forcible rustication, while still others were fleeing persecution or poverty (Guo 2007: 40). They were joined by older Han Chinese who settled in the border region under the zhibian ("helping socialist construction in the borderlands") campaign of the 1950s and 1960s. According to one former fighter's estimate, some thirty thousand volunteers from China joined the BPA between 1968 and 1978 (Wang 2011: 9). Most fought in the base areas across from the Chinese border, which developed their own civil administrations, tax system, police, prisons, schools, and hospitals, issued their own license plates, and, with Chinese help, built hydropower stations (Lintner 1999: 282).

This flight to Burma was unparalleled in that it offered a way to get out of Mao's China without being branded a traitor and also because its participants' motivations displayed a complex mix of resentment against and support for the regime and its ideology. Volunteers from China were far better educated than were local "tribal" soldiers, and they were often given the hardest tasks. They had a very high casualty rate, but those who survived often rose in the ranks. In 1972, when China-Burma relations thawed and some fighting units of the People's Liberation Army were withdrawn, the BPA's military fortunes began to decline and its commanders turned to cultivating and taxing opium. Many volunteers who saw a future for themselves in China returned there (this required permission from the Yunnan Province Foreign Affairs Office), while others defected to Khun Sa's army. In 1975, all "urban youth" were recalled to China, and many were permitted to return to the cities, but many others stayed on in Burma. More returned in the early 1980s when Deng Xiaoping's reforms started. ${ }^{12}$

\footnotetext{
12 Several memoirs have been published by former volunteers (e.g., Wang 2010; 2011) or are available online (e.g., 51nb.com 2009). To mention just one typical life history: Kang Guohua, who was forbidden to join the Red Guards because his father had been classified a capitalist, wanted to wipe away the family's shame by volunteering to fight for Burma's "liberation," and went to Burma in 1969 at the age of nineteen. A friend of Kang's fled to Burma after his brother committed suicide after being attacked by Red Guards. The volunteers recall being so strongly
} 
After Mao's death, China's assistance to the CPB was drastically reduced, and in 1989 it stopped altogether. (A year earlier Thailand had withdrawn support from the Kuomintang.) During this period, opium production and taxes on the Burma-China trade became the party's main source of income (ibid.: 358-61). "Paradoxically," but more in line with the direction China itself was then taking, "the area controlled by ... the CPB became a haven for free trade in then-socialist Burma" (ibid.: 361).

In 1989, BPA troops - principally ethnic Wa but led partly by Chinese officers - rebelled, ousted the CPB's Burman leadership, and gave up their revolutionary ideology. Through Chinese mediation they reached a ceasefire agreement with the Burmese junta in return for a free hand in running their territory, which was split into four "special regions" within Burma's Shan State. Three of these, Number 1 (Kokang), Number 4 (Mong La), and Number 2, with a combined area of about 50,000 square kilometers, were run by Chinese leaders. These were, respectively, the Myanmar National Democratic Alliance Army under Chairman Peng Jiasheng (Phueng Kya-Shin), the National Democratic Alliance Army-Eastern Shan State under Chairman Sai Lin, and the United Wa State Army (UWSA) under Chairman Bao Youxiang (International Crisis Group [henceforth ICG] 2009: 10-12; Haitang Shequ n.d.). According to Chinese accounts, Bao Youxiang hailed from Sichuan and had been sent down to Yunnan for rustication in 1971 (51nb.com 2009). ${ }^{13}$ Sai Lin, too, has been an "educated youth" in Yunnan, but he is mixed Shan-Chinese and born in Burma (Lintner 1999: 507). Peng Jiasheng is an ethnic Chinese from Kokang who had his own local army before joining the BPA and rising to become its vice-commander. Later he was one of the central figures in the 1989 mutiny. During the BPA insurgency, two of the six battalions Peng Jiasheng commanded were staffed by "educated youths" from China (Guo 2007: 44-46). Twelve of the top UWSA commanders are said to be ethnically Chinese (ICG 2010: 4). On account of their relatively high education and political connections, former "educated youth" occupy important administrative positions in all three special regions, as do BPA cadres trained in China and their sons, some of whom were born in China.

The special regions alleviated China's concerns with the insurgencies along the border. They allowed the Burmese junta to pacify the borders after decades of civil war and open them to trade at a time when it was taking its first steps away from a planned economy. They also let local armies keep their arms and some territory and revenue. The regions also appeared to fit the pattern of "special economic zones" that China had introduced a decade

influenced by Chinese films about anti-imperialist heroes that they actually fought with one breast bared for the enemy bullet (51nb.com 2009).

${ }^{13}$ Bertil Lintner, however, describes Bao as a Wa from Burma (1999: 514). 
earlier, or, even more closely, the "special administrative region" (SAR) model that had been agreed on for Hong Kong and Macau under the "one country, two systems" concept. Although the ceasefire agreements were meant to be temporary, the term "special zone" holds continuing fascination for both ethnic insurgencies and the Burmese junta. They presumably hold differing interpretations of it, but its very ambiguity may add to its attractiveness. Thus, the Kachin Independence Organisation, which set up its own special region in Kachin State under a separate ceasefire agreement, proposed to China that the ethnic groups within Burma be granted autonomy along the lines of Hong Kong's and Macau's status (ibid.: 6). ${ }^{14}$ In 2011, with Chinese encouragement, the junta enacted a new law on special economic zones, and that same year the government signed a contract with a Thai company to develop a 250 -square kilometer special economic zone around the southern town of Dawei, complete with a deep sea port and a railway to Thailand (Szep 2012).

The ceasefires, which ended thirty years of warfare, led to an expansion in the production of opium and heroin, and later, after the implementation of opium bans, of methamphetamine (Parker 2006). The latter had been started some years earlier and had made former CPB commanders, now heading splinter groups, "some of the richest men in Burma" (Lintner 2002: 114). A Sino-Burmese border trade agreement signed in 1988 enabled legal trade with China as well. Much of this trade was run by former "sent-down youth" who had returned to China but retained close contacts with special zone leaderships. ${ }^{15}$

The three regions established civilian administrative divisions reminiscent of China's: prefectures (zhou), counties (xian), townships (xiang), and districts (qu) (51nb.com 2009). Political structures were set up with names identical to those in China, such as People's Political Consultative Conferences, and flags and coats of arms modeled on China's were adopted. The regions continued to rely on trade with China for all industrial goods and many food products. Since at least 1992, low-level official contacts have been maintained between the special regions and county-level Chinese authorities (though these have met with disapproval from Peking [ICG 2010: 13] and are controversial within the Yunnan provincial government). For instance, when a representative of the Yunnan Province Foreign Affairs office attended the UWSA's celebration of the twentieth anniversary of the coup against the CPB, Bao Youxiang "expressed gratitude for China's twenty years of support" (ICG 2009: 10, n. 103, 104), and asked for more investment, infrastructure construction, aid, "human resources training," and an expansion of the opium-replacement schemes. Chinese agricultural investors in the regions had benefited from

\footnotetext{
14 For a list of special regions, see Irrawaddy (2004). Thanks to Semuren for pointing this source out to me.

${ }^{15}$ My own 2011 fieldwork in Special Region 4 was arranged through one of these cadres-turned-businessmen.
} 
these Chinese government subsidies since the ban on opium cultivation (ibid.: 12, n. 122; Guo 2007: 63-64). Some members of the special regions' police forces have received training at Yunnan military academies (51nb.com 2009; Wang 2011). In the late 1970s and 1980s, when the Chinese government trained Hmong guerrillas to fight the Vietnam-backed Lao government, the rebels transited through Special Zone Region 4 and, according to Lintner (1999: 402), Sai Lin later tried to use connections he had gained thereby to establish a drug route via Laos.

In the 1990s and 2000s, the special regions benefited from a renewed influx of migration and investment from China. "Educated youth" and other earlier settlers began inviting their relatives and friends to come and benefit from the growing economy. Other migrants are small traders, many of them from Hunan, with no previous connection to the region. While the use of the Chinese language had always been common in the area, the special regions adopted it as the language of education, and for their official communications, which employ a style identical to that used by authorities in China. They also adopted the Chinese currency and connected to China's mobile telephone network and power grid. Bertil Lintner (2002) states that the special regions, particularly Number 4 , also profited as conduits for much illegal emigration from China in the 1990s. ${ }^{16}$

Chinese companies, taking advantage of the opium-substitution subsidies, moved in to plant rubber, sugarcane, tea, and other cash crops (Zhang Ansheng and Zhang Xiaoming 2002; Woods 2011). In 1992, Menghai County, concerned with the influx of drugs from Special Region 4, experimentally planted $10 \mathrm{mu}$ ( 0.3 hectares) of wet rice under the supervision of technicians and a manager from the county's seed company. By 1995, this had expanded to $10,000 \mathrm{mu}$ (660 hectares). By then, Special Region 4 had achieved selfsufficiency in rice and was able to export some to Special Region 2 and to Menghai (Shi 1998). Other counties bordering on the special regions began to follow suit, and in 1996 Zhenkang County signed an agreement with Kokang to develop 30,000 mu (2,000 hectares) of farmland jointly under an opium-replacement contract-farming scheme (Zhao 2011). This incentive accompanied Chinese government pressure on the special regions to ban opium cultivation, which Sai Lin did in 1997. For many years the local governments granted the subsidies, but in 2006 Peking allocated 800 million yuan to fund opium-substitution schemes in Burma and Laos. For part of the population the scheme resulted in a significant rise of incomes; some larger planting households earned 40,000 yuan $(\$ 6,200)$ annually and even bought cars (Zhao 2011). Mong La, however, became known for gambling and prostitution; according to

\footnotetext{
${ }^{16}$ Lintner (2002) claims that migrants aboard the Golden Venture, which ran aground outside New York Harbor in 1993 and attracted global attention to the phenomenon, had all come via Special Region 4.
} 
one report, it attracted three thousand visitors from across the border each day, including many officials. As early as 1993, Special Region Number 4 and Menghai County signed an agreement that allowed day tours, but after the authorization of casinos in 1998, Special Region 4,

used gambling profits ... to fund road construction, public buildings and other infrastructure projects that Kengtung - a town under Burmese control just a few hours away - could only dream of. Mong La's rapid modernization led former prime minister Gen Khin Nyunt to pronounce the city as developed as Rangoon during a visit in 2001. In truth, the city was - and still is - developmentally superior to the capital. ${ }^{17}$ Reports suggest Mong La - the capital of an area that is home to less than 80,000 peoplehas generated up to $\$ 5$ billion in total gambling revenues since casinos were first authorized.... That figure represents an average of nearly $\$ 10,400$ per capita annually from gambling profits generated in Mong La alone, up to the end of 2004, when business at the casinos ground to a halt. By contrast, the average Burmese citizen living in areas controlled by the Burmese regime was estimated to have made just $\$ 1,800$ in 2005 (Parker 2006).

In 2003, concerned with gambling by government officials, China closed Mong La's border to non-local Chinese citizens. Casinos moved to other areas of Special Region 4 (ibid.) and to Kachin State Special Region 3, where a similar crackdown occurred in 2009 after the Chinese media reported incidents of kidnapping and torture of gamblers unable to pay their debts. The Yunnan government responded by cutting off water, telecommunications (disrupting Internet access and thereby the casinos' accounting), power, and roads (ICG 2009: 16). Moreover, according to the International Crisis Group, "Chinese troops ... closed border crossings to casino towns and raided casinos across the border, arresting and fining all Chinese, including casino operators and gamblers" (ibid.: n. 171). Casinos again reopened, now farther from the border, but the National Democratic Alliance Army has also been trying to attract Chinese investment in coal mining and logging.

In 2009, the Burmese army unexpectedly occupied Special Region 1, replaced Peng Jiasheng with his deputy, and transformed the Myanmar National Democratic Alliance Army into a border guard force (ICG 2010: 19). The invasion caused thirty-seven thousand refugees to flee across the border into China, the first such event reported in the Chinese media since the late-1970s flight of ethnic Chinese from Vietnam (ICG 2009: 13). The Burmese government has also demanded that the other "ceasefire armies" join its border guard force, and since the armies have rejected this there are fears that other special regions might be invaded, or even that civil war might return. China reportedly deployed extra troops on the Burmese border in May 2010 (Wade 2010), while the UWSA was said to be recruiting veteran soldiers from China (Kachin News Group 2009). These tensions

\footnotetext{
${ }^{17}$ An almost identical observation is made about Lashio, in Special Zone 2, by Thant Myint-U (quoted in Deb 2011).
} 


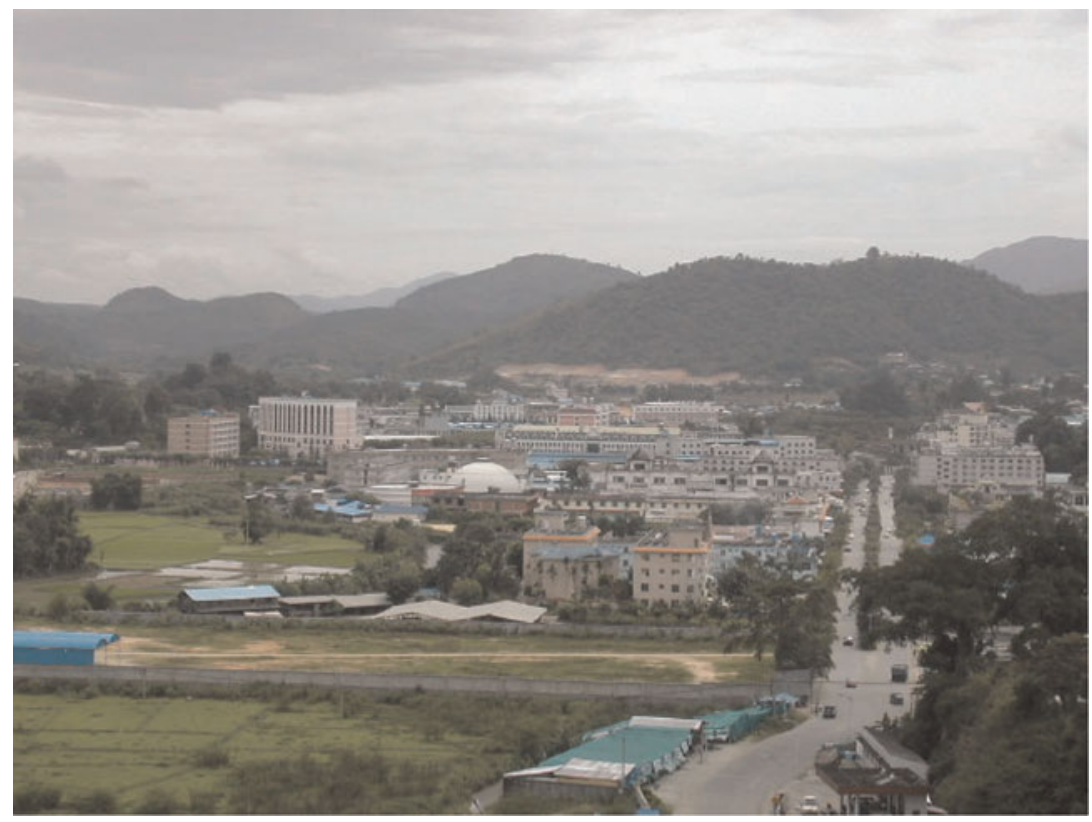

Figure 3 Mong La, Shan State Special Region 4, June 2011. Author's photo.

were a further blow to the casino business (Shan Herald 2009), and investors intensified their search for ways to get out with their capital. In 2011, a resigned atmosphere permeated Special Region 4. With the Chinese government and state-owned corporations concluding more investment agreements with the Burmese junta that sidelined the interests of border trade, special zone officials had little doubt that they would soon lose their autonomy; their only hope was to negotiate relatively favorable terms.

The administration of Special Zone 4 and its sympathizers in China portray Sai Lin and his former BPA cadre as equivalents to their Chinese communist patrons, as leaders who have, despite international isolation and the threat of war, skillfully steered the zone away from the dire poverty and drug trading of twenty years ago to the relative modernity of today. Their reports emphasize infrastructural improvements, school construction, and rising incomes. ${ }^{18}$ But because of the shifting interests of China's central leadership, their gambit of transforming themselves from leaders of the international proletarian revolution

18 An example is the bilingual (Burmese-Chinese) booklet produced for the twentieth anniversary of the special region in 2009: Chan Bang Dong Bu Di Si Tequ Jianqu Ershi Zhou Nian (Twentieth anniversary of Special Region 4, Eastern Shan State). n.p. 


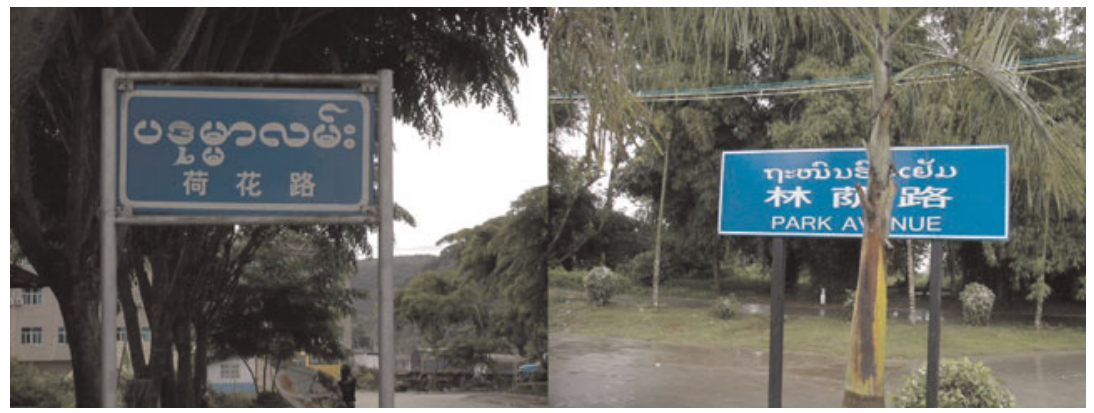

Figure 4 Street signs in Special Region 4 and the Golden Triangle Special Economic Zone, June 2011. Author's photo.

into leaders of an apolitical but quasi-capitalist modernization is almost certain to fail. The best they can hope for is to secure roles as local brokers between Chinese and Burmese officials and capital. Rank-and-file "educated youth" BPA fighters, most of them poor and embittered by their lack of recognition from the Chinese government, have turned to using semi-underground publications to demand their place in history and, often, democratization.

In contrast, the developers of Golden Boten and the Golden Triangle Special Economic Zone are trying to establish themselves as regional modernizers at an opportune moment. In 2008, a master plan for the economic development of Northern Laos, prepared by Chinese specialists on behalf of the Yunnan Province Reform and Development Commission, and presented to the Lao government, proposed setting up new free trade zones along the country's borders and developing tourism concessions, which contractors would operate and control (Northern Laos 2008). This proposal seems to be reflected in Laos' 2009 Law on Investment Promotion, which enables the establishment of Special Economic Zones, defined as "a development zone for urbanization" that may consist of industrial, tourist, free trade, residential, and other kinds of zones (Article 33). This vision is further elaborated in Decree number 443/PM, issued in October 2010, which sets out the criteria for transforming a special zone into a city (Article 33): it must have a population of at least eighty thousand and an infrastructure that includes schools, hospitals, and preferably an international airport.

Such fantastic visions are probably inspired by developers' promotional texts, and also encourage further promises from them. The brochure of GBC asks potential investors to "believe that thousands of people will ... live and develop here with various occupations and identities, to form a huge community, and a modern society." On the back cover of the inaugural January 2008 issue of Luang Namtha Provincial Tourism Magazine, Boten is already described as the "most internationally modernized city in [L]ao," while a 
journalist for a Bangkok-based Chinese-language business magazine describes the Golden Triangle Special Economic Zone as "a miracle," which he attributes to the "diligence, perseverance, idealism, and heroism" of Chinese entrepreneurs venturing into Southeast Asia (Hanzi 2010: 11). A report on Phoenix TV, a popular Hong Kong-based satellite channel, compared Boten to Shenzhen, China's first, legendary special zone, which grew from a fishing village to become one of southern China's largest cities (Phoenix 2010). While these sources are certainly biased, Boten's rows of condo-like buildings make it, in a sense, the most modern-looking place in Laos outside the capital, Vientiane: the sight replicates new urban districts that Chinese companies have in recent years rapidly constructed on the dilapidated outskirts of Kampala and Luanda. What is different about Boten's urbanization is that it is turning spatial hierarchies on their head: the remote borderlands of the nation are, by virtue of their closeness to China, beginning to look more metropolitan than its very center. Thant Myint-U, makes the same point about Lashio in northeastern Burma: "It's a stunning reversal in Burma's geography. What had been remote is now closer to the new center. What were muddy mountain hamlets are now more modern than Rangoon" (quoted in Deb 2011).

The discourse of modernization is ubiquitous in the zones. The Golden Triangle Special Economic Zone promises to "lead local people to shake off the poverty and backwardness" of the "wilderness of old days" and move into a "modern economic development zone," a "green ecocity with a population of no less than 200 thousand" in ten to fifteen years. ${ }^{19}$ In this discourse, familiar from China, modernization is a journey along which humans and nature are transformed together with the investing company, so that "inhospitable and ungovernable places [become] pacified, morally superior, and governable consumer paradises" (Tomba 2009: 610). At a ceremony during which KingsRomans donated fifty motorized rickshaws (tuk-tuks) to Lao residents in the presence of Premier Thongsing, Zhao Wei urged the residents to "change their traditional way of doing business" (Laosez.com 2011). Promotional brochures combine the heroic language of conquering nature, which harkens back to Maoist times, with the lingo of modern management and the vision of urbanization, with the latest buzzwords of sustainability and environmentalism themselves understood as features of modernity. Although the pursuit of capital is never far from the surface, promotional texts for both zones invariably include a promise of cosmopolitanism and world-betterment that transcends economic globalization.

It is easy to dismiss these promises as the sales pitch of Mong La "drug lords wishing to launder their money" (Tan 2010: 6), for whom the Lao government's enthusiasm for special zones came as a godsend. Yet Prime Minister's

19 At: http://www.kingsromans.com and http://www.laosez.com/html/tqgk/ (accessed 16 Feb. 2011). 
Thongsing's desire to "leverage the model function of the special zone" (Huang 2011) is shared, at least in part, by UNIDO - the UN's industrial development organization - and the Asian Development Bank, which run a joint project to "promote the development of special economic zones in Laos." ${ }^{20}$ KingsRomans' insistence that "today's Golden Triangle ... needs to shake off, on the one hand, the old days' shadow of drugs and, on the other hand, poverty and ignorance," 21 and that it is engaged in building an opium "substitution economy" (Hanzi 2010: 12), is a tactic to gain legitimacy with varied audiences: the Lao government, which prioritizes the development of special zones as areas for promoting economic growth, international institutions, and also the Yunnan provincial government, which has described its opiumsubstitution subsidies in Mong La and Kokang as a successful development intervention (Shi Anda 1998; Zhang Ansheng and Zhang Xiaoming 2002; Zhao 2011). Zhao Wei, the chairman of Golden Triangle's economic committee, thinks what he is doing is "not just investment but accumulating merit (jide): by cutting off the Golden Triangle's source of drugs, I can save many people" (Hanzi 2010: 12). Zhao claims to have spent nearly $\$ 10$ million to help projects in the region, including drug eradication initiatives in Burma and schools in Burma and Thailand (ibid.: 16).

These explicit, elaborate claims to be modeling modernity are grounded in two powerful and conflicting discourses. One, which is both visual and textual, replicates the paraphernalia of the Chinese state, from communiqués to ceremonies, and banners to uniforms. These appear to have a dual function: First, they borrow power from the authority of the strong neighboring state as if by synesthesia, by suggesting a connection through the senses without explicitly stating that there is one. But they also borrow efficacy as a developmental regime by imitating the practices of a state associated with developmental powers. When Zhao Wei makes speeches about "responsibility to history," "rapid, healthy development," or "promoting Sino-Lao friendship" (ibid.: 1315), he is not just lionizing himself: he is borrowing the language of state enterprises investing in, say, Lao hydropower. This discourse affirms paternalism, order, discipline, and economic growth, and associates these with the People's Republic of China as a model. Although many Asian states have employed special zones as a development model, in Laos (as in Africa or Papua New Guinea), where they have arrived only in the last few years, they have been specifically associated with China. According to a manager at Golden Triangle, Lao officials returning from training in China, particularly younger ones, have been keen to apply the "Shenzhen model" at home. It is easy to imagine that the familiar trappings of the state are reassuring to these

\footnotetext{
20 Remarks by Sonam Yangchen Rana, UN Resident Coordinator, Lao Plaza Hotel, Vientiane, 16 July 2009; and Chong Chi Nai, ADB Country Director, ibid., 15 Oct. 2010.

21 Introduction to KingsRomans investors' brochure.
} 
officials, who are also engaged in an institutional rivalry with military units that, by entering into joint ventures with Chinese rubber planters, are accumulating wealth, and thus gaining influence within the state.

Yet there is a second discourse upon which claims of modernizing power are based, one of economic and social freedom from discipline imposed by the state. The former vice-chairman of Golden Boten's administrative committee emphasized this when I interviewed him: "This is the SEZ [Special Economic Zone] in the world in which investors have the most rights to invest." Such competitive claims to greater freedom are, of course, central to the attractiveness of special zones, not only for major investors but also to individual fortune-seekers, from gamblers to oilcake vendors. The prominence of gambling, drugs, and sex is arguably not just a product of short-term profit seeking, but also a functional element of this discourse of freedom. Indeed, if the special zones feel both more regulated and more freewheeling than the national territory within which they are enclaved, it is perhaps partly by design.

This design suits the interests of not only investors and fortune-seekers, but also, in some ways, those of the Lao state. This is so in the general sense, which Aihwa Ong and others have noted, that all types of special zones allow states to maintain control flexibly and minimize resource investment. But it is also so in a more specific sense in remote borderlands where state penetration has been very limited. Danielle Tan argues that in northern Laos, "The Chinese presence,"

far from eroding the state ... permits it to adapt to the constraints of globalization.... The new Chinese networks ... will serve as essential mediators between the state and the global economy; ... they will participate in the restructuring of power, providing it the means to adapt to neoliberal globalization, offering it new possibilities of regulating and controlling its territory and population.... Chinese migration, along with the process of regional integration ... grant the Lao state the necessary financial, technological, and human means, which it never had, to access the resources of these territories and to undertake what James C. Scott has called the last enclosure ... to make the northern highlands profitable (n.d.).

Chinese migrants, Tan effectively argues, have regained the function of a "middleman minority" (Bonacich 1973; see also Nyíri 2011) which they had under the colonial authorities (and highland Haw and other Chinese-speaking groups are once again becoming intermediaries for them). These migrants provide farmers with seedlings (mostly of rubber palm, but also of other cash crops), fertilizer, and access to markets, and they collect produce and take care of its passage through the Lao-Chinese border, including by negotiating payments with customs officials. "By producing rent and new opportunities of redistribution among influential personalities, they contribute to the viability of the state. Thus, Chinese investment and migration help render the highlands 'legible,' governable, and profitable for the lowland state while impeding the emergence of a regional bourgeoisie that might threaten the power of the 
current rulers" (Tan 2010: 16), just as it did for colonial rulers and the aristocracy allied with them. According to Tan, if the position of Chinese migrants in northern Laos approaches that of tax farmers, as Tan asserts, then the special zones constitute full-blown tax farms.

\section{EXPERIMENTS WITH SOVEREIGNTY AND VISIONS OF PROGRESS}

"Thinking beyond the nation" has been most productive when it has looked not for the erosion of state sovereignty but for spaces in which the sovereign functions of the state are farmed out to private companies or militaries, whether domestic or foreign, or international structures. The experience of northern Laos suggests that Chinese concessions do not represent a return to colonialism with a new colonizer: the ostentatious presence of Chinese state symbols is not state strategy but rather a synesthetic trick. Slogans and uniforms aside, in comparison to the enclaves of the BPA's armed revolutionary resistance from which the present special zones evolved, the discourse of modernization through which their rulers now justify their existence is technical rather than political.

And yet, to view these special zones as the "business as usual" of developmentalism's “anti-politics machine" (Ferguson 1990), or of neoliberal globalization, which ultimately smooth over disharmony between state and capital for the sake of profit (Ong 2006), is to miss an important dimension of the zones. For one thing, not only do new types of social fields involving Chinese and non-Chinese emerge in the zones, generating new forms of politics, but the zones also fundamentally upset the performative relationship between state and nation. For another, Chinese-managed concessions of various kinds are proliferating around the world, for mining, agriculture, manufacturing, free trade zones, railways, and power-generation (Nyíri 2009; Brautigam and Tang Xiaoyang 2011). While these will probably vary considerably regarding their forms of governance and sovereignty, and patterns of sociality between Chinese and non-Chinese residents, they are also likely to share and reproduce certain symbols, discourses, and forms of discipline associated with modernization of a sort familiar from China. When champions of what Danielle Tan termed "criminal development" deploy the same slogans and rituals as managers of state-owned hydropower enterprises (Lyttleton and Nyíri 2011), they do so to garner legitimacy with both the Chinese and the local state, as well as with investors. But their partaking in a shared discourse of progress, which beyond immediate promises of enrichment gives them a cargo-cult-like appeal among local officials, also justifies and structures actions and aspirations in the zones. This discourse enfolds casinos and dams along the Mekong into a vision of progress that culminates in astonishing images, such as the high-speed railway system that China proposed in 2010, which, it was said, would carry passengers from London to Peking in two days. 
CONCLUSION：DEVELOPMENTALISM AND SOVEREIGNTY

During the Cold War, both ideological sides were committed to the idea of the continual improvability of the human condition, but this view has since fallen out of fashion in the West. It has declined due to the spread of negative assessments of Western development aid; to criticisms of economic growth as the sole indicator of improved well-being and free-market capitalism as the only way to achieve it; and to environmental concerns; and arguably because most Westerners did not feel that their own condition improved over this period. In China, by contrast, both official and popular faith in progress is one of the most enduring legacies of the twentieth century. The nature of progress was redefined along the way, as illustrated in miniature by the way in which, in the special zones of the borderlands, visions of class liberation evolved into those of ecotourism. While this has damaged the credibility of those who have pronounced these ideas from positions of power, it has not undermined the notion of progress itself.

The meshing of private and state fantasies of development explains why the pretensions of special zone developers cannot be dismissed out of hand. A "vice economy" now drives these zones, investors obviously seek to make a quick buck, and the Chinese state has cracked down. But we should not assume from these facts that zone managers and the officials they talk to in Laos and China do not view the zones as at least potential enclaves of progress. (What traction this view has with the Lao more broadly is a different and significant question.) As things now stand, the Golden Triangle Special Economic Zone, located farther than Boten from the punitive reach of Chinese authorities, and with more resources available to it, may well continue to grow. Golden Boten's new investor intends to develop it into a logistical hub. Practices of sovereignty will remain contested, but the enclaves' best insurance against violent reversals of the sort that occurred in Burma is to deliver on their promise of modernization and integrate their economies with those of the "Greater Mekong Subregion."

It is the promise of progress that makes such experiments with sovereignty possible. As was true a hundred years ago, this not only expresses the dominant tenets of the global economy at a given historical moment; it also represents an upheaval in ways of thinking about the future. As before, the situation is rife with threats of violence and destroyed livelihoods, but also with the creativity that makes "new imaginations of community possible" (van der Veer 1996: 7).

REFERENCES

51nb.com. 2009. Miandian Chan Bang Di-yi Tequ Guogan Luntan (Shan State No. 1 Special Region Kokang Forum). At: http://www.51nb.com/forum/viewthread.php? tid=785531 9 (accessed 3 Jan. 2010). 
Agamben, Giorgio. 2005. State of Exception. Kevin Attell, trans. Chicago: University of Chicago Press.

Anderson, Benedict O'G. 1993. Imagined Communities: Reflections on the Origin and Spread of Nationalism, revised ed. London: Verso.

Appadurai, Arjun. 1993. Patriotism and Its Futures. Public Culture 5, 3: 411-30.

Appadurai, Arjun. 1996. Modernity at Large: Cultural Dimensions of Globalization. Minneapolis and London: University of Minnesota Press.

Bayart, Jean-François et al., eds. 2004. Le Royaume concessionnaire: Libéralisation économique et violence politique au Cambodge. Paris: FASOPO.

Bonacich, Edna. 1973. Theory of Middleman Minorities. American Sociological Review 38: 583-94.

Boyarin, Daniel and Jonathan Boyarin. 1993. Diaspora: Generation and the Ground of Jewish Identity. Critical Inquiry 19: 693-725.

Brautigam, Deborah and Tang Xiaoyang. 2011. African Shenzhen: China's Special Economic Zones in Africa. Journal of Modern African Studies 49, 1: 27-54.

Chang, Wen-Chin. 2001. From War Refugees to Immigrants: The Case of the KMT Yunnanese Chinese in Northern Thailand. International Migration Review 35, 4: $1086-105$.

Clifford, James. 1997. Routes: Travel and Translation in the Late Twentieth Century. Cambridge, Mass.: Harvard University Press.

Cooper, Frederick. 2011. Reconstructing Empire in British and French Africa. Past and Present 210 (supplement 6): 196-210.

Cotula, Lorenzo, et al. 2009. Land Grab or Development Opportunity? Agricultural Investment and International Land Deals in Africa. Nottingham: International Institute for Environment and Development, Food and Agriculture Organization of the United Nations, and International Fund for Agricultural Development.

Davis, Sara. 2003. Premodern Flows in Postmodern China: Globalization and the Sipsongpanna Tais. In Alexander Horstmann and Reed L. Wadley, eds., Centering the Margin: Agency and Narrative in Southeast Asian Borderlands. Oxford: Berghahn.

Deb, Siddhartha. 2011. Where China Meets India, by Thant Myint-U-Review. Guardian, 19 Aug. At: http://www.guardian.co.uk/books/2011/aug/19/where-china-meetsindia-review (accessed 6 Sept. 2011).

Diana, Antonella. 2009. Roses \& Rifles: Experiments of Governing on the China-Laos Frontier. PhD thesis, Australian National University, Canberra.

Edwards, Penny. 2005. Outside In: Sino-Burmese Encounters. In Pál Nyíri and Joana Breidenbach, eds., China Inside Out: Chinese Nationalism and Transnationalism. Budapest and New York: Central European University Press.

Fawthrop, Tom. 2011. High Stakes as Laos Turns to Casinos. South China Morning Post, 23 Jan.: 11.

Ferguson, James. 1990. The Anti-Politics Machine: "Development," Depoliticization, and Bureaucratic Power in Lesotho. Cambridge: Cambridge University Press.

Ferguson, James. 2006. Global Shadows: Africa in the Neoliberal World Order. Durham: Duke University Press.

Forbes, Andrew and David Henley. 1997. The Haw: Traders of the Golden Triangle. Bangkok: Asia Film House.

Gilroy, Paul. 1993. The Black Atlantic: Modernity and Double Consciousness. London: Verso.

Glassman, Jim. 2010. Bounding the Mekong: The Asian Development Bank, China, and Thailand. Honolulu: University of Hawai'i Press.

Guo, Xiaolin. 2007. Towards Resolution: China in the Myanmar Issue. Washington, D.C. and Uppsala: Central Asia-Caucasus Institute and Silk Road Studies Program. 
Haitang Shequ. n.d. Chan Bang di-yi, di-er, di-si tequ mingyishang Miandian, shijishang duli de san ge Hanren zhengquan (The First, Second, and Fourth Special Zones in Shan State: nominally Burmese, in reality-independent Chinese polities). At: http://bbs.leshan.cn/read.php?tid=45858 (accessed 15 Sept. 2009).

Hanzi. 2010. Dongmeng jingji yitihua de yonggan kaituozhe: fang Jin Sanjiao Jingji Tequ guanweihui zhuxi, Jinmumian Jituan dongshizhang Zhao Wei xiansheng / The First who Formed ASEAN Economic Model Chairman of Golden Triangle Economic Zone and Kings Romans Group-Mr. Wei Zhao. Dongmeng Shangjie (Bangkok) 11: 10-16.

Hevia, James. 1995. Cherishing Men from Afar. Durham and London: Duke University Press.

Hill, Ann Maxwell. 1998. Merchants and Migrants: Ethnicity and Trade among Yunnanese Chinese in Southeast Asia. New Haven: Yale Southeast Asia Studies.

Huang Tingyan. 2011. 老挝总理通辛・塔马冯 莅临金三角经济特区视察 (Lao Premier Thongsing Thammavong personally inspects Golden Triangle SEZ). 13 Feb. At: http://www.laosez.com/html/tqxw/102.html (accessed 14 Feb. 2011).

International Crisis Group. 2009. China's Myanmar Dilemma. Asia Report no. 177. At: http://www.crisisgroup.org (accessed 25 Dec. 2010).

International Crisis Group. 2010. China's Myanmar Strategy. Asia Briefing no. 112. At: http://www.crisisgroup.org (accessed 25 Dec. 2010).

International Rivers. 2008. Power Surge: The Impacts of Rapid Dam Development in Laos. At: www.internationalrivers.org (accessed 10 June 2009).

Irrawaddy. 2004. List of cease-fire agreements with the Junta. At: http://www.irrawaddy.org/research_show.php?art_id=444 (accessed 20 May 2011).

Kachin News Group. 2009. Thousands of Chinese Vietnam War Veterans Join Wa. 15 Dec. At: http://www.bnionline.net/news/kng/7565-thousands-of-chinese-vietnamwar-veterans-join-wa.html (accessed 10 Sept. 2011).

Keyes, Charles, ed. 1979. Ethnic Adaptation and Identity: The Karen on the Thai Frontier with Burma. Philadelphia: Institute for the Study of Human Issues.

Khaosan Pathet Lao. 2010. Laos, China Prioritise 21 Projects of Transport and Public Works. 25 May. At: http://www.kplnet.net/english/news/newsrecord/25.05.2010/ edn9.htm (accessed 10 June 2010).

KingsRomans. 2010. Laowo guojiaji jingji tequ-Jinsanjiao jingji tequ (Golden Triangle SEZ: a national special economic zone in Laos). Pamphlet. 28 Nov.

Krasner, Stephen D. 2004. Sharing Sovereignty: New Institutions for Collapsed and Failing States. International Security 29: 85-120.

Laosez.com. 2011. 金木棉集团为特区百姓捐赠50辆三轮摩托车 (KingsRomans Group donates fifty motorized rickshaws to zone's common people). 14 Feb. At: http://www.laosez.com/html/tqxw/103.html (accessed 14 Feb. 2011).

Leach, Edmund R. 1954. Political Systems of Highland Burma: A Study of Kachin Social Structure. London: G. Bell \& Son.

Leach, Edmund R. 1960. The Frontiers of "Burma." Comparative Studies in Society and History 3: 49-68.

Le Bail, Hélène and Abel Tournier. 2010. From Kunming to Mandalay: The New "Burma Road." Asie Visions 25. Paris: Centre Asia IFRI.

Lintner, Bertil. 1999. Burma in Revolt: Opium and Insurgency since 1948. Chiang Mai: Silkworm Books.

Lintner, Bertil. 2002. Illegal Aliens Smuggling to and through the Golden Triangle. In Pál Nyíri and Igor Saveliev, eds., Globalizing Chinese Migration: Trends in Europe and Asia. Aldershot, UK: Ashgate. 
Lyttleton, Chris et al. 2004. Watermelons, Bars and Trucks: Dangerous Intersections in Northwestern Laos. Bangkok: Rockefeller Foundation.

Lyttleton, Chris and Pál Nyíri. 2011. Dams, Casinos and Concessions: Chinese Megaprojects in Laos and Cambodia. In Stanley D. Brunn, ed., Engineering Earth: The Impacts of Megaengineering Projects. London and New York: Springer, v. 2.

McCoy, Alfred W. 1999. Requiem for a Drug Lord: State and Commodity in the Career of Khun Sa. In Josiah McC. Heyman, ed., States and Illegal Practices. Oxford: Berg.

Mote, Frederick. 1967. The Rural 'Haw' (Yunnanese Chinese) of Northern Thailand. In Peter Kunstadter, ed., Southeast Asian Tribes, Minorities, and Nations. Vol. 2. Princeton: Princeton University Press.

MqVU. 2010. Chinese Foreign Ministry Issues Warning against Gambling in Laos. 26 Mar. At: http://mqvu.wordpress.com/2010/03/26/hubei-sends-police-team-to-rescuechinese-gamblers-in-boten/ (accessed 10 Jan. 2011).

Northern Laos Industrial Economic Development and Cooperation Planning Preparation Group. 2008. 2008-2020: Planning for Industrial Economic Development and Cooperation in Northern Part of Lao People's Democratic Republic. N.p.

Nyíri, Pál. 2009. Extraterritoriality. EspacesTemps.net, 23 Nov. At: http://espacestemps. net/document7952.html (accessed 22 Jan. 2011).

Nyíri, Pál. 2011. Chinese Entrepreneurs in Poor Countries: A Transnational "Middleman Minority" and Its Futures. Inter-Asia Cultural Studies 12, 1: 145-53.

Ong, Aihwa. 1999. Flexible Citizenship: The Cultural Logics of Transnationality. Durham and London: Duke University Press.

Ong, Aihwa. 2000. Graduated Sovereignty in Southeast Asia. Theory, Culture, and Society 17, 4: 55-75.

Ong, Aihwa. 2006. Neoliberalism as Exception: Mutations in Citizenship and Sovereignty. Durham and London: Duke University Press.

Parker, Clive. 2006. The Rise and Fall of Burma's Casino Capital. Irrawaddy 14, 2. At: http://www.irrawaddy.org/article.php?art_id=5452 (accessed 9 Feb. 2012).

Phoenix TV. 2010. Long xing tianxia. (The dragon travels the world). 12 Oct. At: http:// v.ifeng.com/f/201012/abd93737-0ccf-4d01-b630-aa4f52ecbc51.shtml (accessed 15 Jan. 2011).

Pinkeaw Luangaransri. 2011. China and Economic Civilization in Laos. Paper presented at the workshop "China's Rise: Perspectives from the Mekong Region," Yunnan University, Kunming, 8 Jan.

Prescott, J.R.V. 1977. Frontiers of Southeast Asia. Melbourne: Melbourne University Press.

Sadan, Mandy and Francois Robinne, eds. 2007. Social Dynamics in the Highlands of South East Asia: Reconsidering 'Political Systems of Highland Burma' by E. R. Leach. Leiden: Brill.

Schendel, Willem van. 2002. Geographies of Knowing, Geographies of Ignorance: Jumping Scale in Southeast Asia. Environment and Planning D: Society and Space 20, 6: 647-68.

Scott, James George. 1932. Burma and Beyond. London: Grayson \& Grayson.

Scott, James. 2009. The Art of not Being Governed: An Anarchist History of Upland Southeast Asia. New Haven: Yale University Press.

Shan Herald. 2009. Casinos in Mongla Closed. 10 Sept. At: http://www.shanland.org/ index.php?option $=$ com_content $\&$ view $=$ article \&id $=2721$ : casinos-in-mongla-close-d\&catid=93: general\&Itemid=291 (accessed 27 Feb. 2010).

Shi Anda. 1998. 掹海模式的意义和启示 (The significance of the Menghai model). 中国云南孟海县以缅甸禅邦东部第四特区开展 “绿色进度工程” 的研究报告 (Report on the "green drug ban" project initiated by Menghai County, Yunnan, China, 
and the Number 4 Special Region, Eastern Shan State, Burma). Unpublished report prepared for Chinese authorities.

Shi, Weiyi. 2008. Rubber Boom in Luang Namtha: A Transnational Perspective. Vientiane: GTZ Rural Development in Mountainous Areas (RDMA).

Smith, Richard J. 1998. Mapping China's World: Cultural Cartography in Late Imperial Times. In Wen-Hsin Yeh, ed., Landscape, Power and Culture in Chinese Society. Berkeley: University of California, Institute of East Asian Studies, China Research Monograph 49.

Szep, Jason. 2012. Myanmar's ambitious Dawei project faces uncertainty. Reuters, 5 Feb. At: http://uk.reuters.com/article/2012/02/05/idUKL4E8D336E20120205 (accessed 5 Apr. 2012).

Tambiah, Stanley. 1977. The Galactic Polity: The Structure of Traditional Kingdoms in Southeast Asia. Annals of the New York Academy of Sciences 293: 69-97.

Tan, Danielle. 2010. Du Triangle d'or au Quadrangle économique: Acteurs, enjeux et défis des flux illicites transfrontaliers dans le Nord-Laos. Les notes de l'Irasec, No. 6. Bangkok: Institut de Recherche sur l'Asie du Sud-Est Contemporaine (IRASEC).

Tan, Danielle. n.d. Le rôle des nouveaux réseaux chinois dans la transition néolibérale du Laos. In Vanina Bouté and Vatthana Pholsena, eds., Sociétés et pouvoirs au Laos contemporain. Bangkok: Institut de Recherche sur l'Asie du Sud-Est Contemporaine (IRASEC) (forthcoming).

Thongchai Winichakul. 1994. Siam Mapped: The History of the Geo-Body of a Nation. Honolulu: University of Hawaìi Press.

Tomba, Luigi. 2009. Of Quality, Harmony, and Community: Civilization and the Middle Class in Urban China. Positions 17, 3: 592-616.

Toyota, Mika. 2002. Changing Chinese Identities and Migration in the Borderlands of China, Burma and Thailand. In Pál Nyíri and Igor Saveliev, eds., Globalizing Chinese Migration: Trends in Europe and Asia. Aldershot, UK: Ashgate.

Van der Veer, Peter. 1996. Introduction. In Conversion to Modernities: The Globalization of Christianity. London and New York: Routledge.

Vientiane Times. 2009. Lao Govt Approves Decree on Special Economic Zones. 27 Nov. At: http://www.asianewsnet.net/news.php?id=8835\&sec=2 (accessed 10 June 2009).

Voice of America Lao Service. 2010. Laos: Tonpheung Special Economic Zone Will Greatly Benefit Local People. 31 Mar. At: http://www1.voanews.com/lao/news/ a-52-2010-03-31-voa3-90874749.html (accessed 10 Jan. 2011).

Wade, Geoff. 2010. ASEAN Divides. New Mandala, n.d. At: http://asiapacific.anu.edu. au/newmandala/ (accessed 2 Jan. 2011).

Walker, Andrew. 1999. The Legend of the Golden Boat: Regulation, Trade, and Traders in the Borderlands of Laos, Thailand, China, and Burma. Honolulu: University of Hawaì Press.

Walker, J. T. 1892. Expeditions among the Kachin Tribes on the Northeast Frontier of Upper Burma. Proceedings of the Royal Geographical Society (n.s.) 14: 161-72.

Wang Xi王曦. 2010. Hong fei'e: Saerwenjiang juechang (Red moth: last stand on the Salween). Hong Kong: Tianma.

Wang Xi王曦. 2011. Hong fei'e: Zhonglin lianyu (Red moth: imprisoned in the jungle). Hong Kong: Tianma.

Woods, Kevin. 2011. Rubber Planting and Military-State Making: Military-Private Partnerships in Northern Burma. New Mandala, 4 Feb. At: http://asiapacific.anu.edu.au/ newmandala/2011/02/04/rubber-planting-and-military-state-making.html (accessed 11 Feb. 2011).

Zhang Ansheng and Zhang Xiaoming. 2002. New Ideas on Immigration. Journal of Yunnan Public Security College 3: 89-92 (in Chinese). 
Zhao Wenrui 赵文瑞. 2011. 云南镇康县甘蔗 “替代种植”惠及缅甸便民 (Crop substitution by Yunnan's Zhenkang County benefits Burmese borderlanders). Yunnan Tangwang www.ynsugar.com, 20 Apr. At: www.ynsugar.com/Article/DTXX/ 201104/28594.html (accessed 2 May 2011).

Abstract: The highlands of mainland Southeast Asia have famously been the locus of "Zomia," polities resistant to control by lowland nation-states, but this relative resilience has been due to their marginality. However, as even remote borderlands connect to the market economies of what has been labeled the "Greater Mekong Subregion," these semi-independent polities are trying to transform themselves from isolated drug enclaves into regional paragons of economic modernity labeled "Special Economic Zones." The main actors in this transformation are ethnic Chinese migrant capitalists who embrace the economic rhetoric of mainland China's "growth model" to create respectability and to evoke images of a cosmopolitan future as they build casinos in the rainforest. The zones' claim to be the vanguard of modernity rests on two mutually contradictory sets of symbols: a mimicry of Chinese state paraphernalia designed to conjure up the efficacy of a strong developmental state, and the discourse of freedom from state control. This article examines the transformation of zones of political and criminal resistance into zones of economic development from a historical perspective of changing practices of sovereignty and shifting understandings of development. 